\title{
THE EUROPEAN UNION SERIES
}

\section{General Editors: Neill Nugent, William E. Paterson, Vincent Wright}

The European Union series is designed to provide an authoritative library on the European Union, ranging from general introductory texts to definitive assessments of key institutions and actors, policies and policy processes, and the role of member states.

Books in the series are written by leading scholars in their fields and reflect the most up-to-date research and debate. Particular attention is paid to accessibility and clear presentation for a wide audience of students, practitioners and interested general readers.

The series consists of four major strands:

- general textbooks

- the major institutions and actors

- the main areas of policy

- the member states and the Union

\section{Published titles}

Justin Greenwood

Representing Interests in the European Union

Fiona Hayes-Renshaw and Helen Wallace

The Council of Ministers

Simon Hix and Christopher Lord Political Parties in the European Union

\section{Brigid Laffan}

The Finances of the European Union

Janne Haaland Matláry

Energy Policy in the European

Union

\section{Title of Series \\ Series Standing Order \\ ISBN 978-0-333-69352-0}

If you would like to receive future titles in this series as they are published, you can make use of our standing order facility. To place a standing order please contact your bookseller or, in case of difficulty, write to us at the address below with your name and address, the title of the series and the ISBN quoted above. (If you live outside the United Kingdom we may not have the rights for your country, in which case we will forward your order to the publisher concerned.)

Customer Services Department, Macmillan Distribution Ltd Houndmills, Basingstoke, Hampshire RG21 6XS, England 


\section{Forthcoming}

Simon Bulmer and Drew Scott European Union: Economics, Policy and Politics

David Millar, Neill Nugent and

William E. Paterson (eds)

The European Union Source Book

John Peterson and Elizabeth

Bomberg

Decision-making in the European

Union

Ben Rosamond

Theories of European Integration

Richard Sinnott

Understanding European Integration

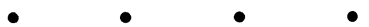

Simon Bulmer and Wolfgang Wessels

The European Council (Second

Edition)

Renaud Dehousse

The Court of Justice: A Brief

Introduction

David Earnshaw and David Judge

The European Parliament

Neill Nugent

The European Commission

Hjalte Rasmussen

The Court of Justice

Anne Stevens

The Administration of the European Union

David Allen and Geoffrey Edwards The External Economic Relations of the European Union

Michelle Cini and Lee McGowan Competition Policy in the European Union

Martin Holland

The European Union and the Third World

Anand Menon

Defence Policy and the European Union
James Mitchell and Paul McAleavey Regionalism and Regional Policy in the European Union

John Redmond, René Schwok and

Lee Miles

Enlarging the European Union

Margaret Sharp and John Peterson Technology Policy in the European Union

Hazel Smith

The Foreign Policy of the European Union

Mark Thatcher

The Politics of European High

Technology

Rüdiger Wurzel

Environmental Policy in the

European Union

Simon Bulmer and

William E. Paterson

Germany and the European Union

Phil Daniels and Ella Ritchie

Britain and the European Union

Alain Guyomarch, Howard Machin and Ella Ritchie

France in the European Union

Other titles planned include

European Union: A Brief

Introduction

The History of the European Union

The European Union Reader

The Political Economy of the

European Union

Social Policy

Monetary Union

Political Union

The USA and the European Union

The European Union and its

Member States

Reshaping the States of the Union

Italy and the European Union

Spain and the European Union 


\section{Political Parties in the European Union}

Simon Hix

and

Christopher Lord

Macmillan Education 
POLITICAL PARTIES IN THE EUROPEAN UNION

Copyright (C 1997 by Simon Hix and Christopher Lord

Softcover reprint of the hardcover 1st edition 1997 978-0-333-60920-0

All rights reserved. No part of this book may be used or reproduced in any manner whatsoever without written permission except in the case of brief quotations embodied in critical articles or reviews.

For information, address:

St. Martin's Press, Scholarly and Reference Division, 175 Fifth Avenue, New York, N.Y. 10010

First published in the United States of America in 1997

This book is printed on paper suitable for recycling and made from fully managed and sustained forest sources.

ISBN 978-0-333-60921-7 ISBN 978-1-349-25560-3 (eBook) DOI 10.1007/978-1-349-25560-3

Library of Congress Cataloging-in-Publication Data

Hix, Simon.

Political parties in the European Union / Simon Hix and

Christopher Lord.

p. $\mathrm{cm}$. - (The European Union series)

Includes bibliographical references and index.

ISBN 978-0-312-17291-6. — ISBN 978-0-312-17292-3(pbk.)

1. Political parties-European Union countries. I. Lord, Christopher. II. Title. III. Series. 


\section{Contents}

List of Tables and Figures

vii

Preface

ix

List of Abbreviations

xii

1 Introduction 1

Why Study Political Parties in the European Union? 1

Political Parties and Party Systems $\quad 7$

A History of Party Politics in the EU 11

Argument and Organisation of the Book 16

2 Shape of the EU Party System 21

Parties and Their Environment $\quad 21$

Dimensions of Party Competition $\quad 23$

Position and Strength of the Party Families 27

Shape of the EU Party System $\quad 49$

3 Organisation of Parties in the EU 54

Organigram of a Party in the EU System 55

One, Three or Fifteen Organisations in Each Party? 57

The Making of Party Policy on Europe 67

Party Adaptation to a Difficult Environment $\quad 74$

4 Party Groups in the European Parliament:

Election and Formation $\quad 77$

Identifying the Party Groups in the EP $\quad 77$

Political Parties and the Selection and Election of MEPs 84

The European Elections in 1994: An Example 90

Group Formation, Change and Composition 93

$\begin{array}{ll}\text { Conclusions } & 108\end{array}$ 
5 Party Groups in the European Parliament:

Institutional Environment and Inner Workings

The Party Groups and the Powers and Functions of the EP

The Party Groups and the Committees of the EP

Group Weeks: Decision-Making within the Groups

Conference of Presidents

The Party Groups in the Plenaries of the Parliament

Conclusion

6 Party Groups in the European Parliament: An Evaluation of their Performance

Cohesion of the Party Groups

The Coherence and Stability of the Party System in the European Parliament

Conclusion

\section{Parties Beyond the Parliament}

Three Phases of Party Development beyond the Parliament

Internal Institutionalisation of the Party Federations

External Links to the EU Institutions

Party Leaders' Meetings and the European Council

From 'Transnational Party Cooperation' to 'Nascent Euro-Parties'

8 Conclusion: Towards a Europe of Parties

A Turning Point: Europe des patries or Europe des partis?

A Clash of Paradigms: International versus Internal Politics

Is the EU a 'Party Democracy'?

Implications for the Design of EU institutions 


\section{List of Tables and Figures}

\section{Tables}

2.1 Critical junctures, cleavages and party families in EU politics

2.2 The Christian Democrats 30

2.3 The Conservatives 31

2.4 The Liberals 34

2.5 The Socialists 37

2.6 The Greens 39

2.7 The Radical Left 41

2.8 The Extreme Right 43

2.9 The Regionalists 46

2.10 The Anti-Europeans 48

2.11 Strengths of political blocs and party families $\quad 52$

4.1 Composition of EP groups by national party 80

4.2 Age, gender and professional background of MEPs by party group $\quad 83$

4.3 Previous political experience of members of members of the PES and the EPP 84

5.1 How the PES and EPP organised a group week, 11-15 September $1995 \quad 126$

5.2 Participation rates of MEPs from different groups in the plenary votes of the EP 135

5.3 Alignments between the party groups in the EP 139

6.1 Domestic cleavages of government and opposition across the main party groups of the EP 141

6.2 Indices of agreement: levels of voting cohesion for the party groups in the EP, 1984-9 and July 1994December 1995 
6.3 Range of opinion within party groups on (i) left-right issues and (ii) European integration

6.4 Leadership structures of the party groups and percentage of membership participating in leadership positions

6.5 Concentration and fragmentation of the party groups

6.6 Measures of the transnational character in the party groups

6.7 Seat shares of the party groups, 1979-95 (\%)

6.8 Alternatives to a PES/EPP duopoly? Possible leftright coalitions in a bipolarised EP

7.1 Party-institution linkages in the 1970s and 1980s

7.2 Party-institution linkages in the 1990s

7.3 Dates and venues of the party leaders' meetings

8.1 From a 'Europe of nations' to a 'Europe of parties'

8.2 Members of the Santer Commission recruited from the Euro-parties

\section{Figures}

2.1 Positions of the party families

3.1 Organigram of a political party in the EU system 56

3.2 The making of party policy on European issues 69

4.1 Hemicycle of the European Parliament

4.2 The proportion of MEPs from each group with service in EP before 1994

6.1 Main changes in group composition between elections, 1989-95

6.2 Left-right range of party groups

7.1 Shifting socioeconomic alliances in the European Council

7.2 Types of parties in the EU system

8.1 Competition between Euro-party platforms in the EU policy/space 


\section{Preface}

At the start of the European integration process in the early 1950s, several scholars predicted a central role for party politics in the construction of a European Community. For example, Ernst Haas devoted two chapters of his seminal work on The Uniting of Europe to predictions of how party competition at the domestic and European levels could promote integration (Haas, 1958). However, it was not until the decision in the early 1970 s to hold direct elections to the European Parliament that a wider community of scholars began to focus on the role of political parties in European Community politics. Many of these new scholars argued that the first elections to the EP would facilitate the emergence of pan-European parties. For example, David Marquand optimistically expected a 'Europe des partis' (Europe of parties) (Marquand, 1978). Nevertheless, a seminal work from this period - Geoffrey and Pippa Pridham's Transnational Parties in the European Community - constituted the first attempt at a comprehensive framework for analysing the organisational and behavioural links between the three key elements of the EC party system: the EP party groups, the European party federations, and the domestic parties in the EG member states (Pridham and Pridham, 1981).

However, the first European elections failed to produce a transnational mobilisation of political forces in Europe or coherent European-level party organisations. A deep disillusionment consequently set in among the Euro-party advocates. Few could now envisage political parties ever being able to challenge the national governments as the main articulators of citizens' interests and the main actors in European-level decision-making. As a result, political parties all but disappeared from the research agenda of scholars of European integration.

By the early 1990s, nonetheless, political parties have again emerged as (in Haas's words) 'crucial carriers of integration'. First, with the increased powers granted to the EP under the Single 
European Act and the Maastricht Treaty, the behaviour of the EP party groups has a more direct impact on EU policy-making. Second, beginning with the drafting of the Maastricht Treaty in the 1990-91 Intergovernmental Conferences, the Socialist, Christian Democrat and Liberal party federations have held 'party leaders' summits' before each meeting of the European Council. As a direct result of these party leaders' summits, a 'Party Article' (138A) was inserted in the Maastricht Treaty: the first reference to the role of political parties in any EC Treaty or legislation. Finally, European integration has itself emerged as a major new 'cleavage' and source of intra- and interparty competition in the domestic arena. This was evident in the ratification of the Maastricht Treaty; in the 1994 EP elections; and in the arguments about the application of 'convergence criteria' for economic and monetary union. Many mainstream parties now have deep internal divisions on the question of Europe, and old and new parties and movements present anti-European platforms at the fringes of most domestic party systems.

Consequently, in the mid-1990s it is impossible to ignore the fundamental significance of political party organisation, behaviour and competition at the national and European levels in the continued development towards political, economic and monetary union in Europe. However, this book is the first attempt since Pridham and Pridham (1981) to present an integrated framework for understanding how party organisation and behaviour are linked throughout the complex and fragmented system of the EU - in the European Parliament, at national level, and within and between the other EU institutions. As part of a wider series of books on EU politics, this book fills a gap in the existing empirical research on EU politics and policy. The book includes a large quantity of new material based on several years of primary research (through interviews, direct observation and content analysis) in the European Parliament, at several party leaders' summits, and in a number of national capitals. However, this book is more than simply an empirical addition or summary. By placing party loyalties, actions, organisations and policies at the centre of our analysis, we present a fundamentally different theoretical and methodological perspective of how European integration and politics is best understood.

Numerous people have contributed to this book, either through interviews or through less formal comments and observations. We must thank in particular David Bell, Elmar Brok MEP, Peter BrownPappamikail, Ken Collins MEP, Richard Corbett, Pat Cox MEP, 
Giorgos Dimitrakopoulos MEP, Brendan Donnelly MEP, Glyn Ford MEP, Fernand Herman MEP, Thomas Jansen, Karl Magnus Johansson, Francisco Lucas Pires MEP, Michael McGowan MEP, Giandomenico Majone, Graham Mather MEP, Neil Nugent, Manuel Porto MEP, Tapio Raunio, Barry Seal MEP, Michael Shackleton, Tony Teasdale, Thomas Tindemans, John Tomlinson MEP, Martin Westlake and Philip Whitehead MEP.

CHRISTOPHER LORD

SimON Hix 


\section{List of Abbreviations}

AGALEV Ecology Party (Belgium: Flanders)

AN National Alliance (Italy)

CG Canaries Coalition Party (Spain)

GD Christian Democrats (Italy)

CDA Christian Democrat Party (Netherlands)

GDC Catalan Democratic Convergence Party (Spain)

GDS Christian Democrat Party (France)

CDS-PP Centre Democrat Party (Portugal)

GDU Christian Democratic Union (Germany)

CG Greens (Ireland)

Con Gonservative Party (UK)

CSP Confederation of Socialist Parties

CSP-EVP European People's Party (Belgium: German minority)

CSU Christian Social Union (Bavarian sister party of CDU)

GVP Christian Democrat Party (Belgium: Flanders)

D'66 Radical Liberal Party (Netherlands)

DP Democratic Party (Luxembourg)

DUP Democratic Unionist Party (UK: N. Ireland)

EG European Community

EGGP European Co-ordination of Green Parties

Ecofin Council of Economic and Finance Ministers

Ecolo Ecology Party (Belgium:Wallonia)

ECOSY EC Organisation of Socialist Youth

ECSC European Coal and Steel Community

EDF European Democratic Federation

EDG European Democratic Group (EP group 1973-92)

EDU European Democratic Union

EFA European Free Alliance (Regionalists)

EFGP European Federation of Green Parties

ELDR European Liberal and Democratic Reform (federation and group in EP) 


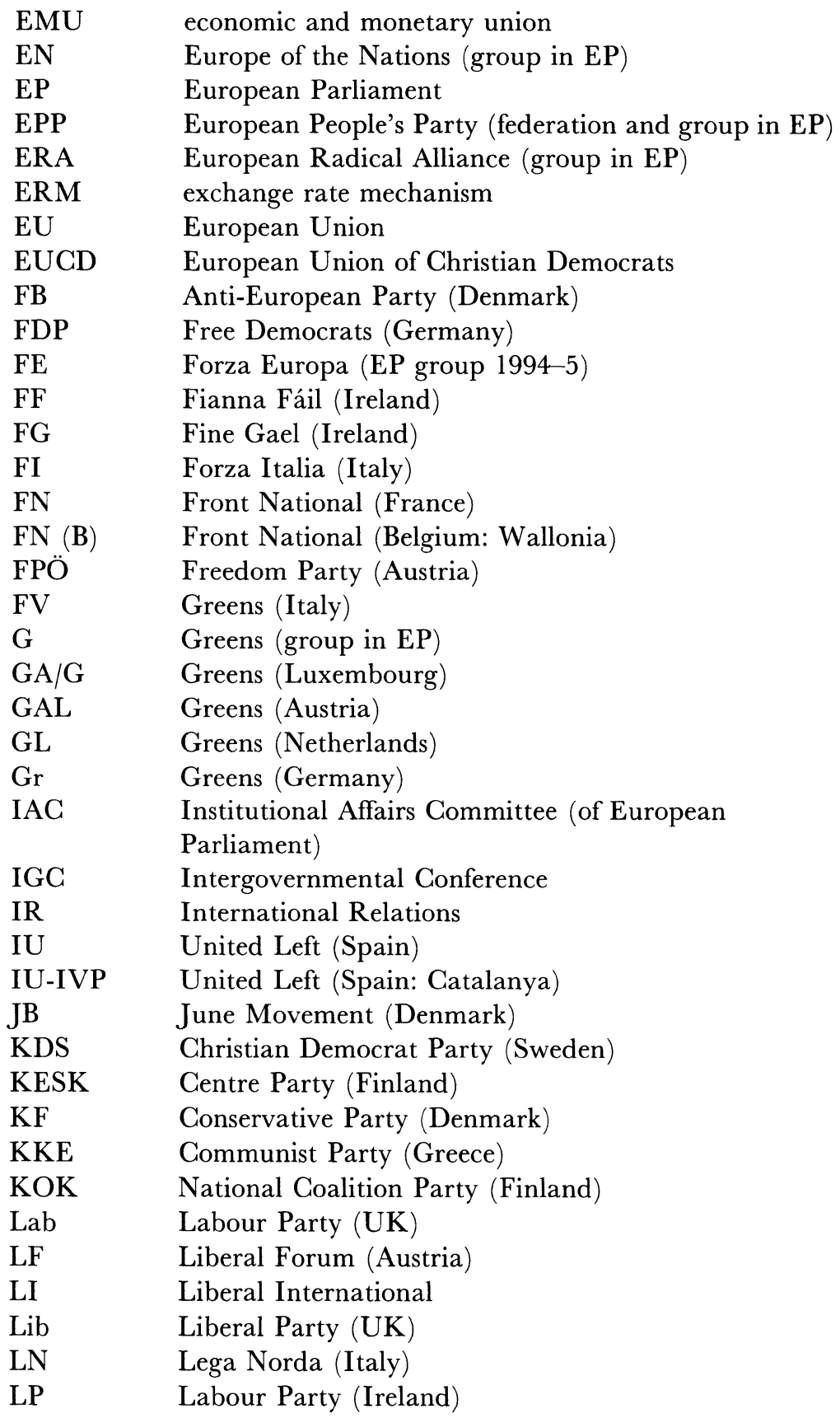




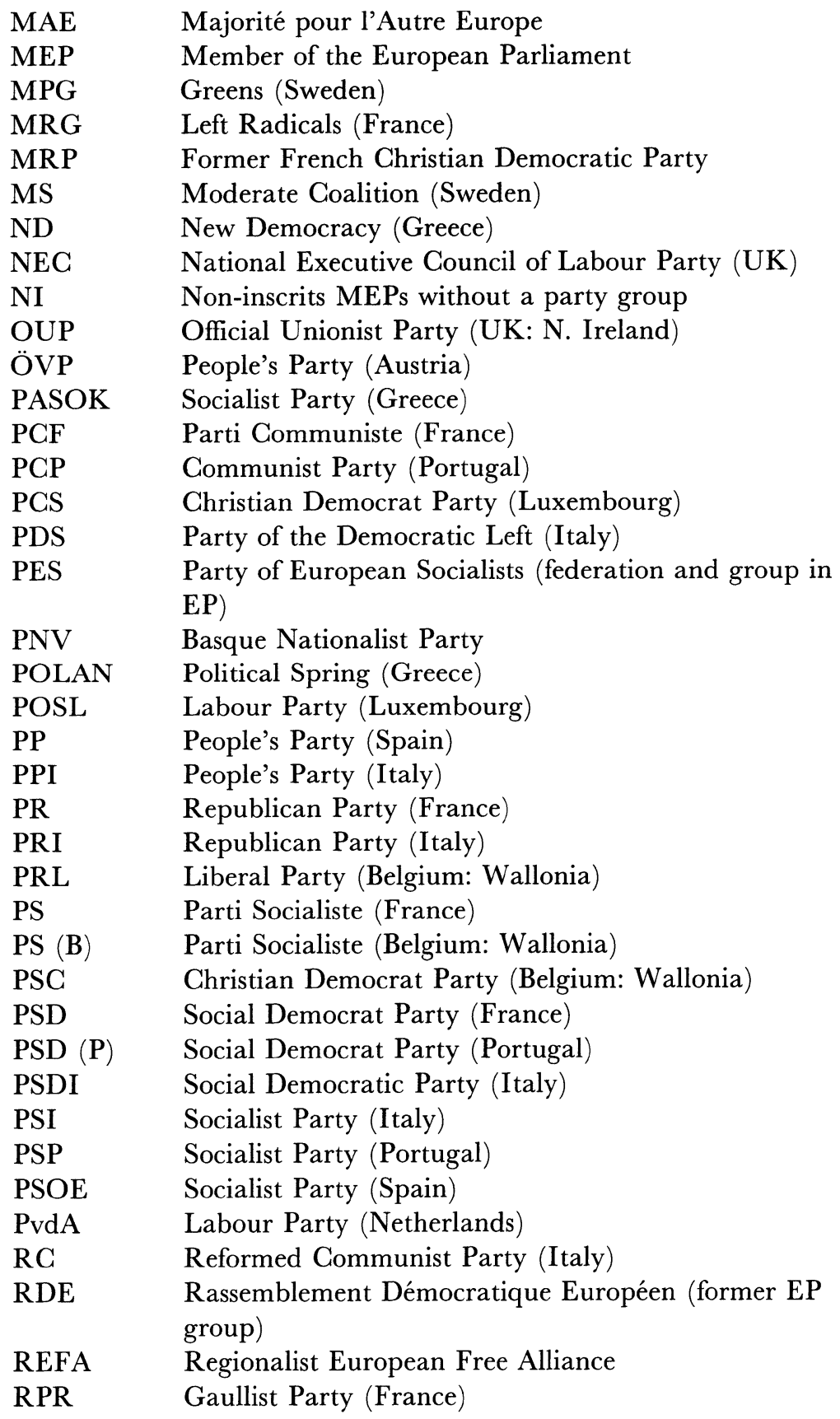




$\begin{array}{ll}\text { RV } & \text { Radical Liberal Party (Denmark) } \\ \text { SAP } & \text { Social Democratic Labour Party (Sweden) } \\ \text { SD } & \text { Social Democrat Party (Denmark) } \\ \text { SDLP } & \text { Social Democratic and Labour Party (UK: N. Ireland) } \\ \text { SDP } & \text { Social Democrat Party (Finland) } \\ \text { SEA } & \text { Single European Act } \\ \text { SF } & \text { Socialist People's Party (Denmark) } \\ \text { SFP } & \text { Swedish People's Party (Finland) } \\ \text { SGP/GPV } & \\ \text { /RPF } & \text { Protestant Confessional Party (Netherlands) } \\ \text { SI } & \text { Socialist International } \\ \text { SNP } & \text { Scottish Nationalist Party (UK: Scotland) } \\ \text { SP } & \text { Socialist Party (Belgium: Flanders) } \\ \text { SPD } & \text { Social Democratic Party (Germany) } \\ \text { SPÖ } & \text { Socialist Party (Austria) } \\ \text { SVP } & \text { South Tyrol Party (Italy) } \\ \text { SYN } & \text { Synaspismo tis Aristeras (Greece) } \\ \text { UDC } & \text { Catalan Democratic Union (Spain) } \\ \text { UDF } & \text { Union Démocratique Française } \\ \text { UEL } & \text { Union of the European Left (group in EP) } \\ \text { UPE } & \text { Union for Europe (group in EP) } \\ \text { V } & \text { Liberal Party (Denmark) } \\ \text { V (S) } & \text { Left Party (Sweden) } \\ \text { VAS } & \text { Vasemmistoliitto (Finland) } \\ \text { VB } & \text { Vlaams Blok (Belgium: Flanders) } \\ \text { VIHR } & \text { Greens (Finland) } \\ \text { VLD } & \text { Flemish Liberal Party (Belgium: Flanders) } \\ \text { VU } & \text { Volksunie (Belgium: Wallonia) } \\ \text { VVD } & \text { Liberal Party (Netherlands) } \\ & \end{array}$

